\title{
Occurrence of the sabretooth cat Smilodon populator (Felidae, Machairodontinae) in the Cuvieri cave, eastern Brazil
}

\author{
Artur Chahud
}

\begin{abstract}
The saber-toothed cat Smilodon populator, typical of the Pleistocene of South America, is known for its teeth, cranial bones, and post-cranial bones (humerus, radius, ulna, femur, tibia, fibula, astragalus, and phalanges). A specimen found in the Cuvieri Cave in Brazil based on small bones (calcaneal, ectocuneiform, and phalanges) is described and commented here. The osteological material has a complete calcaneal and an ectocuneiform that adds data on S. populator. The specimen is comparable in size to that of an adult lioness and represented the largest predator in the region. The associated fauna and age obtained for the material were also discussed.
\end{abstract}

Artur Chahud. Laboratory for Human Evolutionary Studies, Department of Genetics and Evolutionary Biology, Institute of Biosciences, University of São Paulo. Rua do Matão 277, São Paulo, SP 05508-090, Brazil. arturchahud@yahoo.com ORCID https://orcid.org/0000-0001-7690-3132

Keywords: Lagoa Santa; Pleistocene; Carnivora; South America; anatomy

Submission: 19 December 2019. Acceptance: 11 May 2020.

\section{INTRODUCTION}

The Cuvieri cave is part of the Lagoa Santa karst complex, consisting of two passages, one obstructed and the other with $1.5 \mathrm{~m}$ height and $1 \mathrm{~m}$ width, giving access to its interior. The cave has three small vertical cavities, natural traps, which were called Locus 1, 2, and 3, with $16 \mathrm{~m}, 4 \mathrm{~m}$, and $8 \mathrm{~m}$ depth, respectively (Hubbe et al., 2011). Since 1974 , with the discovery of terrestrial sloth Catonyx cuvieri, the Cuvieri Cave has been the target of scientific interest which is reflected in the work done on dating, paleontology, taphonomy, and comparison with other paleontological and archaeological sites (Hubbe et al., 2011; Haddad-Martim et al., 2017).

The Felidae family emerged in South America since the American Faunal Interchange of the Late Pliocene. Currently only three genera occur in South America, Puma, Panthera, and Leopardus. However, after the faunal exchange three other genera attributed to the Machairodontinae subfamily were reported, Smilodon, Homotherium (Mones

Chahud, Artur. 2020. Occurrence of the sabretooth cat Smilodon populator (Felidae, Machairodontinae) in the Cuvieri cave, eastern Brazil. Palaeontologia Electronica, 23(2):a24. https://doi.org/10.26879/1056

palaeo-electronica.org/content/2020/3045-occurrence-of-the-sabretooth 
and Rinderknecht, 2004), and Xenosmilus (Rincón et al., 2011), the first being the most common in the fossil record.

The genus Smilodon is part of the Machairodontinae, an extinct subfamily of Felidae, and includes three species; S. gracilis, S. fatalis, and S. populator. The main diagnostic feature of this subfamily is the very elongated canine teeth compared to other predators, from which its colloquial name "saber tooth cats" originates. The Smilodon populator species is, so far, the largest and the last to be extinct (Antón, 2013; Christiansen and Harris, 2005; Chimento et al., 2019).

Remains of Smilodon populator have been registered in almost all countries in South America (Berta, 1985, Kurtén and Werdelin, 1990; Ubilla et al., 2004; Rincón, 2006; Prieto et al., 2010). Studies developed by Hubbe et al. (2011) named the presence of a large Felidae, initially identified as Smilodon populator. The purpose of this contribution is the presentation with comments on the osteological material of this specimen and its identification.

\section{MATERIAL AND METHODS}

The osteological material of the Cuvieri Cave (Figure 1) collected comes from "Locus" 2. According to Hubbe et al. (2011) the sediment found in this location was poorly consolidated, which favored excavation and more careful exploration, with detailed stratigraphy and taphonomy data being obtained.
The specimen presented a small number of materials for study, identification, and classification. According to Hubbe et al. (2011) the distribution of these bones was more concentrated in the corners and extremities of "Locus" 2, despite this scattering bone parts can be considered as belonging to the same individual, since they are compatible in size to those of a large feline, and there are no repeated bone parts. The specimen is represented by only 11 bone parts that were scattered throughout the cavity. An ectocuneiform bone, CVL2-13122, was dated and was $10790 \pm 60 \mathrm{BP}$ at $14 \mathrm{C}$ yr BP and $12.880-12.720$ cal yr BP.

The material and registration numbers are deposited at the Laboratório de Estudos Evolutivos Humanos (LEEH) of the Universidade de São Paulo.

\section{SYSTEMATIC PALAEONTOLOGY}

Order CARNIVORA Bowdich, 1821 Family FELIDAE Gray, 1821

Subfamily MACHAIRODONTINAE Gill, 1872

Tribe SMILODONTINI Kurtén, 1963

Genus SMILODON Lund, 1842

Figure 2, Figure 3, Figure 4, Figure 5

Type species. Smilodon populator Lund, 1842

Material. The identified material consists of a fragmented right calcaneal (CVL2 15315), complete left calcaneal (CVL2 12157), complete proximal phalanx (CVL2 14207), four intermediate phalanges (CVL2 13300, CVL2 13333, CVL2 13400,

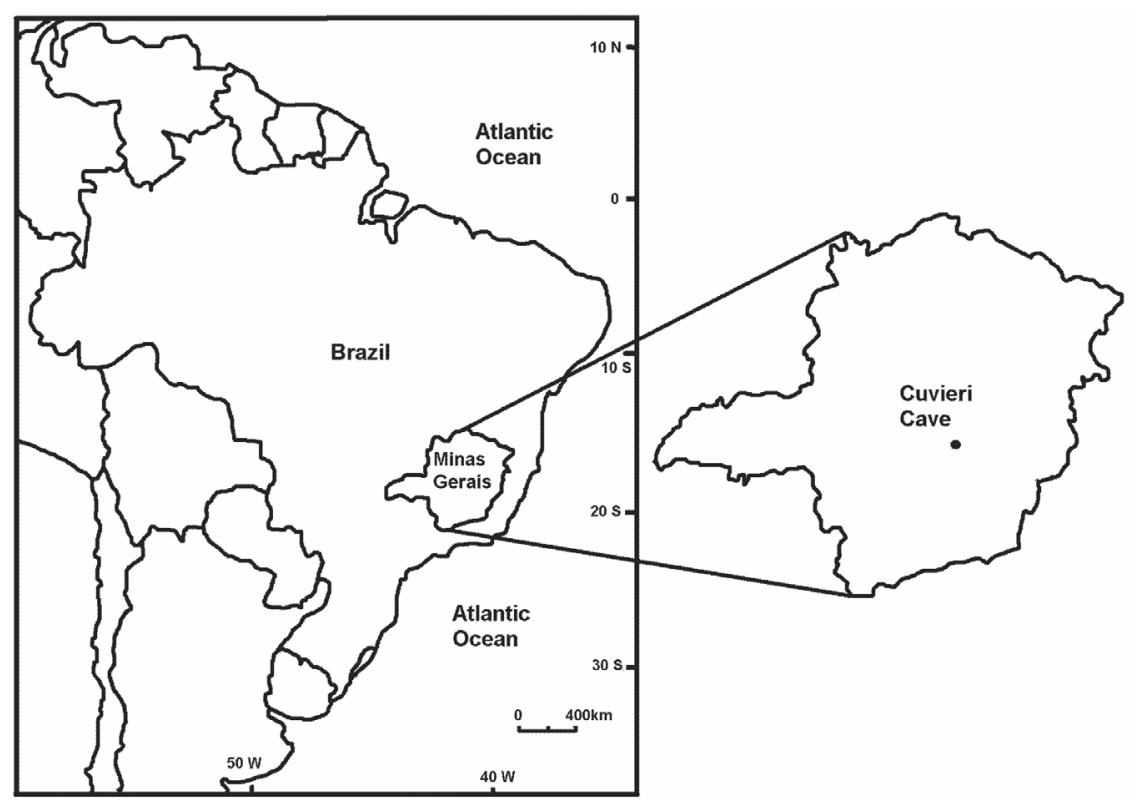

FIGURE 1. Location of the Cuvieri Cave, Lagoa Santa region. State of Minas Gerais, Brazil. 
CVL2 15187), two fragmented distal phalanges (CVL2 14309, CVL2 14532), distal part of metatarsal (CVL2 12475) and one right ectocuneiform bone (CVL2 13122).

General characteristics and comparison. It is possible to compare the osteological material found with large species attributed to the genus Panthera. In Figures 2-4 the calcaneal and ectocuneiform bones were compared to the equivalents of an adult lioness (Panthera leo).

Calcaneal. Comparing the calcaneal, the specimen found in the Cuvieri Cave has the most robust and dense tuberosity (tuber calcis), and the astragalar facets are larger, wider and slightly closer to the cuboid rim than in that of the lioness.

The sustentacular facets, As2 and As3 (Figure 2), have great contact with each other, and As3 basically represents an extension of As2. Compared to the genus Panthera, it has a small extension that links these facets (Figure 3A-D). The process supporting the second facet (As2) or support is more robust and prominent in proportion to the total size of the calcaneal, mainly seen in dorsal view (Figure 3 ).

The As3 astragalar facet is larger and more evident than in the lioness and extends to the cuboid facet. The navicular facet $(\mathrm{Na})$ is next to the As3 facet and both are in direct contact with the cuboid articular facet.

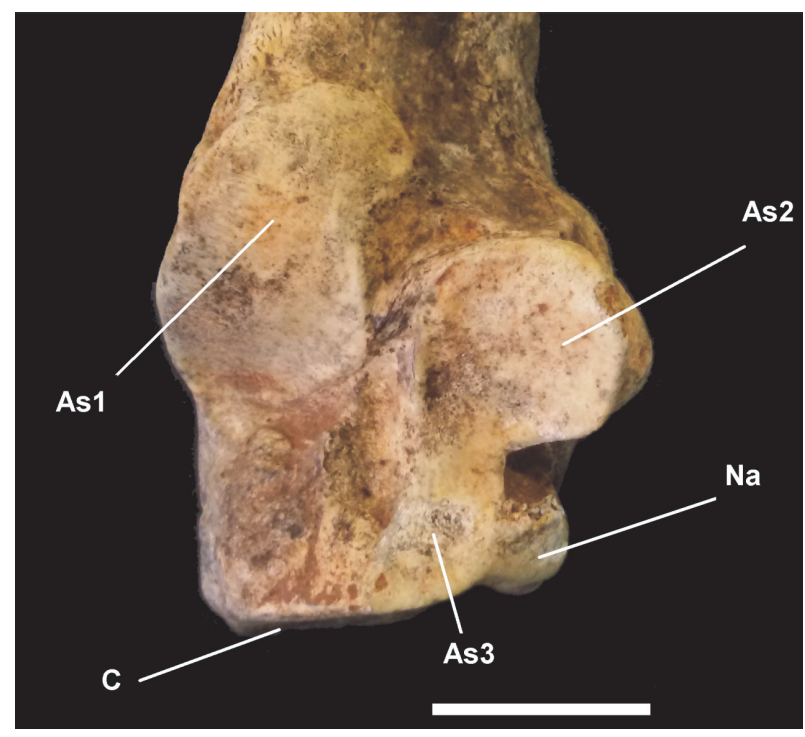

FIGURE 2. Detail of the right calcaneal articulatory region CVL2 15315. As1 - External astragalar facet or ectal facet; As2 and As3 - internal astragalar facets or sustainable facets; $\mathrm{Na}$ - facet articulate with the navicular; C - Articulation facet with cuboid. Scale bar equals $20 \mathrm{~mm}$.
The ectal facet (As1) is larger, wider, and less elongated than observed in the genus Panthera and does not invade the tuberosity.

The cuboid facet $(C)$ differs from the lioness since it occupies a larger area, reaching the plantar border, being straight and flat on this side to the central part (Figure $3 \mathrm{E}$ ), but presents a concavity close to the contact with the navicular facets $(\mathrm{Na})$ and of the astragalar facet (As3).

Ectocuneiform. The right ectocuneiform is more compressed in proximo-distal direction than those in recent large felines. The plantar projection with groove to the tendon of the long fibular muscle has an open hook shape and less prominent curvature than that of the lioness (Figure 4C-D).

The articulating facet with the navicular tapers and stretches to the plantar region, while observing a small projection on the lioness (Figure 4B).

The opposite facet, which articulates to the metatarsal III, is very similar in both (Figure 4A). The plantar projection of this surface is much shorter and relatively small compared to that of a lion of similar size (Figure 4C-E).

Viewed from the inside, the plantar facet of the second metatarsal spans the distal border near the dorsal part of the ectocuneiform. On the outer surface, the cuboid facet is larger than that of the lioness and extends along the proximal edge and approaches the dorsal edge.

Metatarsal and phalanges. The metatarsal and phalanges are indistinguishable in size to those from a recent large feline, such as tigers, lions, or jaguars, as observed in the single phalanx, CVL2 14207. The other specimens had wear, polish (Figure $5 \mathrm{E}-\mathrm{H}$ ), or many breaks, as in the case of the ungual phalanges and the metatarsal (Figure 5A, $5 C-D)$.

The main measurements performed are available in Table 1.

Discussion. Smilodon populator was considered to be the sole representative of the genus Smilodon in South America until evidence was found in the Andean region of Ecuador and Peru, and recently in Uruguay of $S$. fatalis (Kurten and Werdelin, 1990; Manzuetti et al. 2018) and S. gracilis in the Venezuelan Andes (Rincón et al, 2011). Manzuetti et al. (op. cit.) suggested that $S$. populator and $S$. fatalis lived together at the same time and region and Christiansen and Harris (2005) commented that although $S$. populator is larger, it is not uncommon to find adult individuals of similar size to $S$. fatalis.

Comparing the ectocuneiform and calcaneal sizes it is possible to infer that the specimen is 


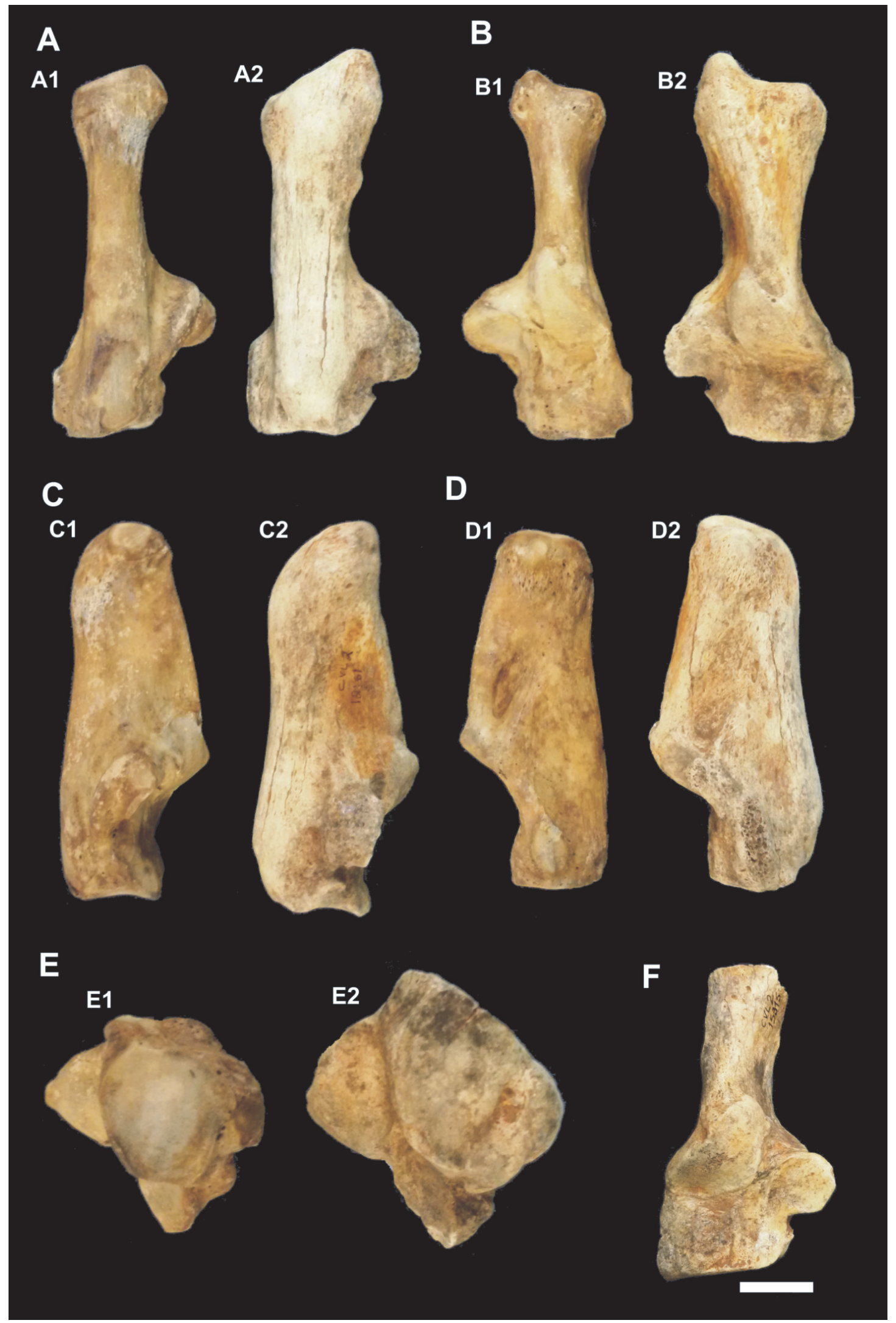

FIGURE 3. Calcaneus. A-F) Left Calcaneus. A) Dorsal view; B) Astragalar view; C and D) Lateral view; E) Distal view; F) Right Calcaneus. A.1-E.1) Adult lioness (Panthera leo) A.2-F) Smilodon populator. Scale bar equals $20 \mathrm{~mm}$. 


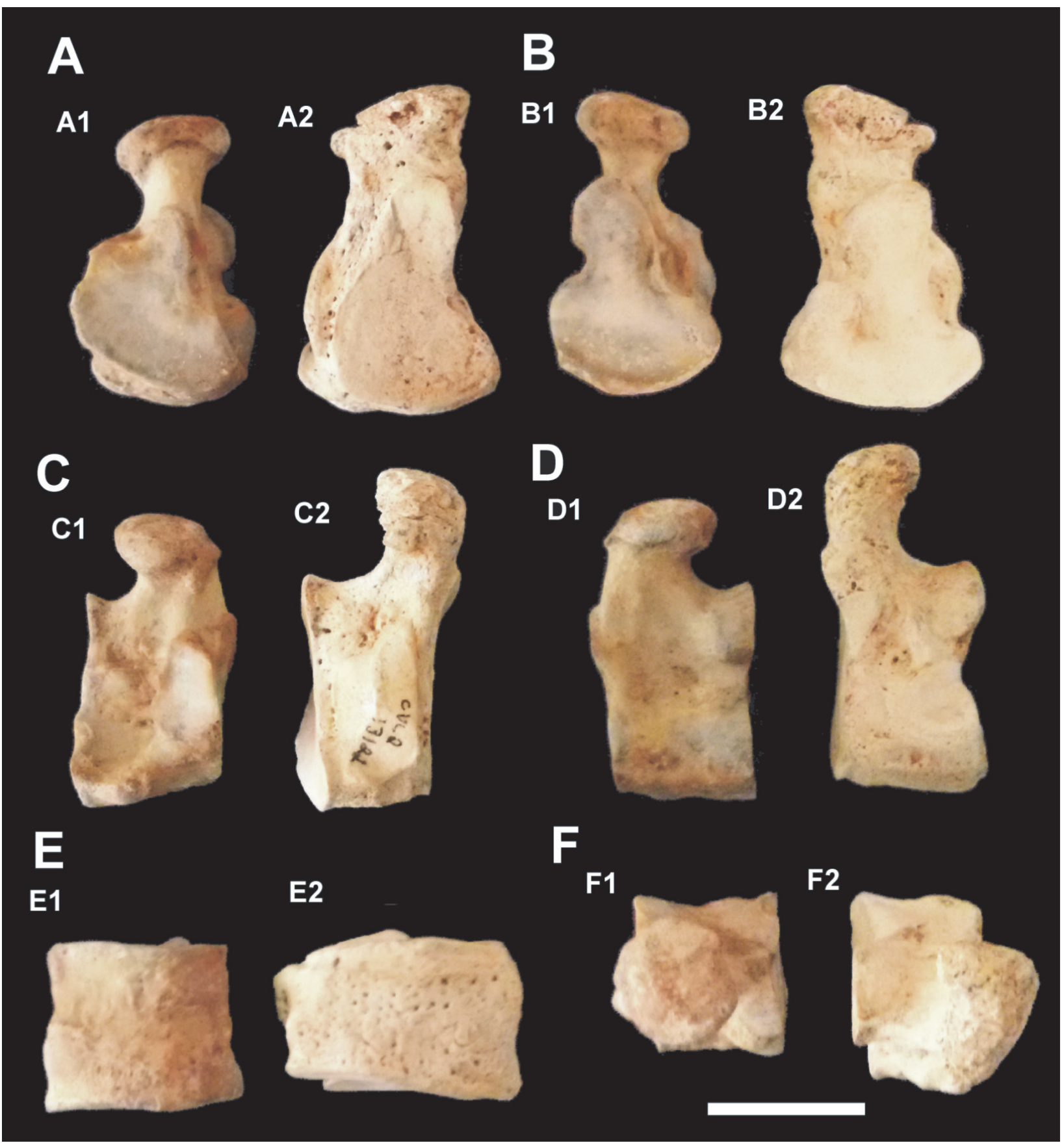

FIGURE 4. Right Ectocuneiform. A) Distal view; B) Proximal view; C) Internal view; D) External view; E) Dorsal view; F) Plantar view. A1-F1) Adult lioness (Panthera leo); A2-F2) Smilodon populator. Scale bar equals $20 \mathrm{~mm}$.

close to the Pleistocene felines Smilodon fatalis, $S$. populator and Panthera gombaszogensis, and $P$. onca augusta (Merriam and Stock, 1932; Hemmer et al., 2010, Argant and Argant, 2011; Baryshnikov, 2011; Scaferla et al., 2013) in length and width and smaller than that of large extinct felines such as $P$. atrox and P. fossilis (Merriam and Stock, 1932; Sabol, 2014; Chimento and Agnolin, 2017).
The proportions of left calcaneal and right ectocuneiform width and length measurements of the Cuvieri Cave specimen with those described for S. fatalis, by La Brea by Merriam and Stock (1932), the Brazilian specimen is slightly more robust than would be expected for a $S$. populator of similar size to $S$. fatalis. 


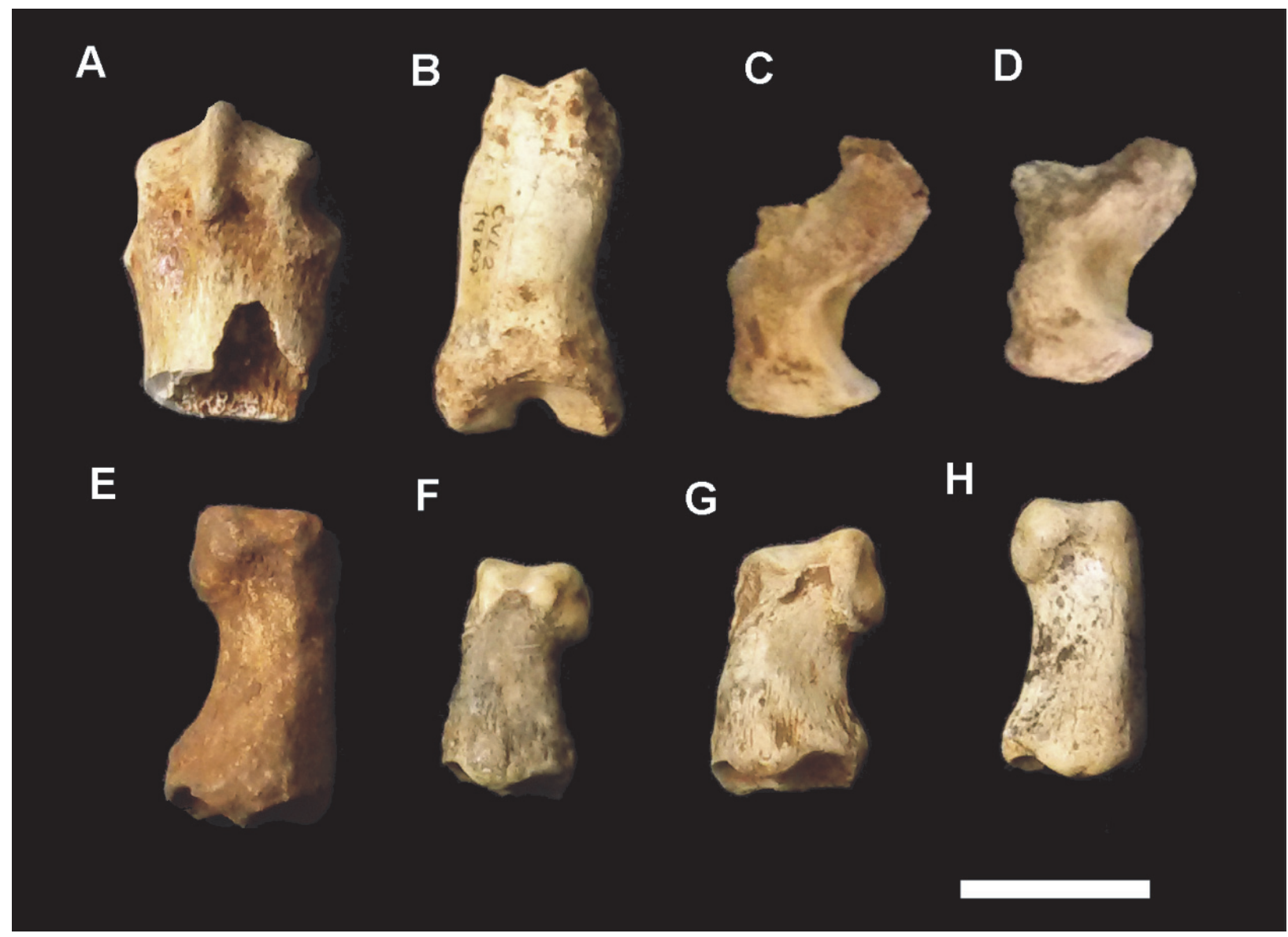

FIGURE 5. Identified osteological material. A) Distal part of metatarsal (CVL2 12475); B) Proximal phalanx (CVL2 14207); B-C) Ungual phalanges (CVL2 14532; CVL2 14309) E-H) Intermediate phalanges (CVL2 15187; CVL2 13333; CVL2 13400; CVL2 13300). Scale bar equals $20 \mathrm{~mm}$.

Smilodon populator occurrences are common in southeastern Brazil. Lund (1842) originally identified and described this species in the Lagoa Santa region, where several specimens were found in various caves, including phalanges and large canine teeth. Other specimens were dated and described, being the specimen found in the Abismo Iguatemi Cave, State of São Paulo, which presented the best specimen with the skull and several preserved bone parts (Ferreira and Karmann, 2002; Castro and Langer, 2008, 2011; Hubbe et al., 2013), revealing important information about the species.

The existence of several specimens of Smilodon populator allowed the registration of various ages for several specimens in South America, and it is clear that the specimens occurred during the late Pleistocene, especially in the last 100,000 years from the Pleistocene to the Early Holocene. Most of the reported ages ranged from 25,0009,000 years (Berta, 1985; Kurtén and Werdelin,
1990; Hubbe et al., 2013; Prevosti and Martin, 2013; Prevosti et al., 2013; Bocherens et al., 2016), with one exception coming from northeast Brazil dating from 93,900 years, using the ESR method, being the oldest of this species (Kinoshita et al., 2017).

\section{ASSOCIATED FAUNA}

The osteological material found in Cuvieri Cave consists mainly of animals of recent fauna, such as Tayassuidae, Cervidae, rodents, small reptiles and anurans, and few occurrences of extinct animals. Among the extinct animals found there are two species of Xenarthra Scelidotheriinae typical of the Lagoa Santa region, Catonyx cuvieri and Valgipes bucklandi (Hubbe et al., 2011), the Cuniculidae Cuniculus rugiceps (Mayer et al., 2016) and a new species of Vulturidae Pleistovultur nevesi (Alvarenga et al., 2008). 
TABLE 1. Measurements (in millimeters) of osteological material found in Cuvieri Cave.

\begin{tabular}{|c|c|c|c|}
\hline Bone part & Number & & $\begin{array}{l}\text { Measurements } \\
(\mathrm{mm})\end{array}$ \\
\hline \multirow[t]{18}{*}{ Left Calcaneal } & CVL2 12167 & Greatest length & 96.8 \\
\hline & & Greatest width measured across astragalar facets As1 and As2 & 42.1 \\
\hline & & $\begin{array}{l}\text { Greatest width across cuboid surface measured from astragalar } \\
\text { facet As } 2 \text { to outer side }\end{array}$ & 47.9 \\
\hline & & $\begin{array}{l}\text { Greatest width of outer face measured normal to plantar Border and } \\
\text { to edge of outer astragalar facet }\end{array}$ & 44.7 \\
\hline & & $\begin{array}{l}\text { Calcaneal tuber length from top of ectal facet to most Uppermost } \\
\text { point of calcaneal tuberosity }\end{array}$ & 52.00 \\
\hline & & Length from top of ectal facet to base of cuboid facet & 44.00 \\
\hline & & Projection of peroneal tubercle from midline & 16.5 \\
\hline & & Projection of sustentacular facet from midline & 27.6 \\
\hline & & Width of cuboid facet & 31.00 \\
\hline & & Mediolateral width of calcaneal tuber & 29.00 \\
\hline & & Anteroposterior width of tuber & 32.00 \\
\hline & & Length of ectal facet & 31.5 \\
\hline & & Width of ectal facet & 17.00 \\
\hline & & Length of sustentacular facet & 24.8 \\
\hline & & Width of sustentacular facet & 19.9 \\
\hline & & Tuber length from uppermost projection of sustentacular facet & 48.9 \\
\hline & & $\begin{array}{l}\text { Width of calcaneal head at widest point including sustentacular } \\
\text { facet }\end{array}$ & 41.0 \\
\hline & & Length from cuboid facet to bottom of sustentacular facet & 17.0 \\
\hline \multirow{13}{*}{$\begin{array}{l}\text { Right Calcaneal } \\
\text { (Fragmented) }\end{array}$} & CVL2 15315 & Greatest width measured across astragalar facets As1 and As2 & 42.3 \\
\hline & & Calcaneal tuber length from top of ectal facet to most & 48.0 \\
\hline & & Uppermost point of calcaneal tuberosity & 51.0 \\
\hline & & Length from top of ectal facet to base of cuboid facet & $\sim 14.0$ \\
\hline & & Projection of peroneal tubercle from midline & 29.0 \\
\hline & & Projection of sustentacular facet from midline & 31.0 \\
\hline & & Width of cuboid facet & $\sim 23.0$ \\
\hline & & Mediolateral width of calcaneal tuber & 32.0 \\
\hline & & Length of ectal facet & 27.6 \\
\hline & & Width of ectal facet & 18.4 \\
\hline & & Length of sustentacular facet & 25.0 \\
\hline & & Width of sustentacular facet & 18.9 \\
\hline & & Length from cuboid facet to bottom of sustentacular facet & 18.0 \\
\hline \multirow{3}{*}{$\begin{array}{l}\text { Right } \\
\text { Ectocuneiform }\end{array}$} & CVL2 13122 & Greatest dorsoplantar length & 38.0 \\
\hline & & Greatest proximodistal diameter & 15.6 \\
\hline & & Greatest width across metatarsal articulation & 22.6 \\
\hline \multirow[t]{3}{*}{ Metatarsal III } & CVL2 12475 & Greatest width in the distal part & 23.0 \\
\hline & & Greatest width of the joint & 18.9 \\
\hline & & Greatest dorsoplantar length & 19.8 \\
\hline \multirow[t]{2}{*}{ Phalanx 1} & CVL2 14207 & Greatest length & 39.57 \\
\hline & & Greatest width & 19.8 \\
\hline
\end{tabular}


TABLE 1 (continued).

\begin{tabular}{lrc}
\hline \multicolumn{1}{c}{ Bone part } & Number & $\begin{array}{c}\text { Measurements } \\
\text { (mm) }\end{array}$ \\
\hline Phalanx 2 & CVL2 13333 Greatest length & 25.0 \\
& Greatest width & 18.6 \\
Phalanx 2 & CVL2 15300 Greatest length & 29.15 \\
& Greatest width & 14.6 \\
Phalanx 2 & CVL2 13400 Greatest length & 29.0 \\
& Greatest width & 16.0 \\
Phalanx 2 & CVL2 15187 Greatest length & 34.0 \\
& Greatest width & 17.7 \\
Phalanx 3 & CVL2 14309 Greatest dorsoplantar length & 27.2 \\
(Fragmented) & CVL2 14532 Greatest dorsoplantar length & 25.0 \\
$\begin{array}{l}\text { Phalanx 3 } \\
\text { (Fragmented) }\end{array}$ & & \\
\hline
\end{tabular}

The osteological material was found next to several carcasses of Cervidae, but none of them has predatory activity marks by large animals, and only rodent or small carnivorous marks, such as Canidae Cerdocyon, were observed. The same was found in other parts of the Cuvieri Cave. Probably the whole animal was there at some point and because of the period of exposure or fragmentation by other animals that subsequently fell there (pigs and deer), most of the bones that persisted are small or massive (calcaneal and phalanges), which are easily buried or protected, while bones with a larger surface area (femur, humerus, and scapula) and fragile bones (vertebrae and cranial bones) have been destroyed. Prevosti and Vizcaino (2006) suggest that Smilodon populator was at the top of the food web and could have captured an animal of 1 ton. All associated animals found would be potential prey.

\section{CONCLUSIONS}

The Cuvieri Cave was not used as a refuge for food or housing, as there was no evidence of gathering or hunting activity and the cavity probably served as a trap. Remains of Smilodon popula- tor have been documented in Venezuela, Brazil, Paraguay, Uruguay, Argentina, Bolivia, and Chile. The age obtained by Hubbe et al. (2011) is very close to those measured in Chilean Patagonian specimens (Pietro et al., 2010), which are among the most recent of this species, in the PleistoceneHolocene boundary.

Smilodon populator is the only species of Smilodon reported in Brazil, but with the discovery of Smilodon fatalis in Uruguay the hypothesis that both coexisted should not be disregarded. The specimen found is similar in size to that of a $S$. fatalis but is more robust. It would be in accordance with the proportions of a medium to small $S$. populator.

\section{ACKNOWLEDGEMENTS}

The author thanks M.A. Aragão for support. The author also thanks Dr. M. Mercedes Martinez Okumura responsible for LEEH (Laboratory for Human Evolutionary Studies), Department of Genetics and Evolutionary Biology, Institute of Biosciences of the University of São Paulo which allowed the preparation of fossils in her laboratory.

\section{REFERENCES}

Alvarenga, H., Brito, G.R.R., Migotto, R., Hubbe, A., and Höfling, E. 2008. Pleistovultur nevesi gen. et sp. nov. (Aves: Vulturidae) and the diversity of condors and vultures in the South American Pleistocene. Ameghiniana, 45(3):613-618.

Antón, M. 2013. Sabertooth, First Edition. Indiana University Press, Bloomington. 
Argant, A. and Argant, J. 2011. The Panthera gombaszogensis story: the contribution of the Château Breccia (Saône-et-Loire, Burgundy, France). Quaternaire, Centre National de la Recherche Scientifique, Hors-série, 4:247-269.

Baryshnikov, G.F. 2011. Pleistocene Felidae (Mammalia Carnivora) from the Kudaro Paleolithic cave sites in the Caucasus. Proceedings of the Zoological Institute RAS, 315:197-226.

Berta, A. 1985. The status of Smilodon in North and South America. Contributions in Science, Natural History Museum of Los Angeles County, 370:1-15.

Bocherens, H., Cotte M., Bonini, R., Scian, D., Straccia, P., Soibelzon, L., and Prevosti. F. J. 2016. Paleobiology of sabretooth cat Smilodon populator in the Pampean Region (Buenos Aires Province, Argentina) around the Last Glacial Maximum: insights from carbon and nitrogen stable isotopes in bone collagen. Palaeogeography, Palaeoclimatology, Palaeoecology, 449:463-474. https://doi.org/10.1016/j.palaeo.2016.02.017

Castro, M.C. and Langer, M. C., 2008. New postcranial remains of Smilodon populator Lund, 1842 from southeastern Brazil. Revista Brasileira de Paleontologia, 11:199-206. https:// doi.org/10.4072/rbp.2008.3.06

Castro, M.C. and Langer, M.C., 2011. The mammalian fauna of Abismo Iguatemi, southeastern Brazil. Journal of Cave and Karst Studies, 73:83-92. https://doi.org/10.4311/jcks2010pa0140

Chimento, N.R. and Agnolin, F.L. 2017. The fossil American lion (Panthera atrox) in South America: palaeobiogeographical implications. Comptes Rendus Palevol, 16:850-864.

Chimento, N.R., Agnolin, F.L., Soibelzon, L., Ochoa, J.G., and Buide, V. 2019. Evidence of intraspecific agonistic interactions in Smilodon populator (Carnivora, Felidae). Comptes Rendus Palevol, 18(4):449-454. https://doi.org/10.1016/j.crpv.2019.02.006

Christiansen, P. and Harris, J. M. 2005. Body size of Smilodon (Mammalia: Felidae). Journal of Morphology, 266(3):369-84. https://doi.org/10.1002/jmor.10384

Faure, M. and Guérin, C. 2014. Smilodon populator et Protocyon troglodytes, deux superprédateurs du Pléistocène supérieur de la Serra da Capivara (Piauí) au Nordeste du Brésil. Annales de Paléontologie, 100:283-295. https://doi.org/10.1016/j.annpal.2014.01.004

Ferreira, N.B. and Karmann, I. 2002. Descobertas paleontológicas na região de Apiaí-SP. Boletim Informativo Geovisão, 10(4):7-8.

Haddad-Martim, P.M., Hubbe, A., Giannini, P.C.F., Auler, A.S., Piló, L.B., Hubbe, M., Mayer, E., Wang, X., Cheng, H., Edwards, R.L., and Neves, W.A. 2017. Quaternary depositional facies in cave entrances and their relation to landscape evolution: the example of Cuvieri Cave, eastern Brazil. Catena, 157:372-387. https://doi.org/10.1016/j.catena.2017.05.029

Hemmer, H., Kahlke, R.D., and Vekua, A.K. 2010. Panthera onca georgica ssp. nov. from the Early Pleistocene of Dmanisi (Republic of Georgia) and the phylogeography of jaguars (Mammalia, Carnivora, Felidae). Neues Jahrbuch fuer Geologie und Palaeontologie Abhandlungen, 257:115-127. https://doi.org/10.1127/0077-7749/2010/0067

Hubbe, A., Haddad-Martim, P.M., Hubbe, M., Mayer, E.L., Strauss, A., Auler, A.S., Piló, L.B., and Neves, W.A., 2011. Identification and importance of critical depositional gaps in pitfall cave environments: the fossiliferous deposit of Cuvieri Cave, eastern Brazil. Palaeogeography, Palaeoclimatology, Palaeoecology, 312:66-78. https://doi.org/10.1016/j.palaeo.2011.09.010

Hubbe, A., Hubbe, M., Karmann, I., Cruz, F.W., and Neves, W.A. 2013. Insights into Holocene megafauna survival and extinction in southeastern Brazil from new AMS ${ }^{14} \mathrm{C}$ dates. Quaternary Research, 79:152-157. https://doi.org/10.1016/j.yqres.2012.11.009

Kinoshita, A., Mollemberg, M., Santana, W., Figueiredo, A.M.G., Guidon, N., Luz, M. F., Guérin, C., and Baffa, O. 2017. ESR dating of Smilodon populator from Toca de Cima dos Pilão, Piauí, Brazil. Applied Radiation and Isotopes, 120:66-70. https://doi.org/10.1016/ j.apradiso.2016.11.016

Kurtén, B. and Werdelin, L. 1990. Relationships between North and South American Smilodon. Journal of Vertebrate Paleontology, 10(2):158-169. https://doi.org/10.1080/ 02724634.1990 .10011804

Lund, P.W. 1842. Blik paa Brasiliens Dyreverden for Sidste Jordomvaeltning. Tredie Afhandling: Forsaettelse af Pattedyrene. Det Kongelige Danske Videnskabernes Selskabs Naturvidenskabelige og Mathematiske Afhandlinger, 9:137-208.

Manzuetti A., Perea D., Ubilla M., and Rinderknecht A., 2018. First record of Smilodon fatalis Leidy, 1868 (Felidae, Machairodontinae) in the extra-Andean region of South America (late Pleistocene, Sopas Formation), Uruguay: taxonomic and paleobiogeographic implications. Quaternary Science Reviews, 180:57-62. https://doi.org/10.1016/j.quascirev.2017.11.024 
Mayer, E.L., Hubbe, A., Kerber, L., Haddad-Martim, P.M., and Neves, W., 2016. Taxonomic, biogeographic, and taphonomic reassessment of a large extinct species of paca from the Quaternary of Brazil. Acta Palaeontologica Polonica, 61(4), 743-758. https://doi.org/10.4202/ app.00236.2015

Merriam J.C. and Stock C. 1932. The Felidae of Rancho La Brea. Carnegie Institute Publication, Washington.

Mones, A. and Rinderknecht, A. 2004. The First South American Homotheriini (Mammalia: Carnivora: Felidae). Comunicaciones Paleontologicas Museo Nacional de Historia Natural y Anthropologia, 2(35):201-212.

Prevosti, F.J., Forasiepi, A., and Zimicz, N., 2013. The evolution of the Cenozoic terrestrial mammalian predator guild in South America: competition or replacement? Journal of Mammalian Evolution, 20:3-21. https://doi.org/10.1007/s10914-011-9175-9

Prevosti, F.J. and Martin, F.M. 2013. Paleoecology of the mammalian predator guild of the Southern Patagonia during the latest Pleistocene: ecomorphology, stable isotopes, and taphonomy. Quaternary International, 305:74-84. https://doi.org/10.1016/ j.quaint.2012.12.039

Prevosti, F.J. and Vizcaíno, S.F. 2006. Paleoecology of the large carnivore guild from the late Pleistocene of Argentina. Acta Palaeontologica Polonica, 51:407-422.

Prieto, A., Labarca, R., and Sierpe, V. 2010. New evidence of the sabertooth cat Smilodon (Carnivora: Machairodontinae) in the late Pleistocene of southern Chilean Patagonia. Revista Chilena Historia Natural, 83:299e307. https://doi.org/10.4067/S0716078X2010000200010

Rincón, A. 2006. A first record of the Pleistocene saber-toothed cat Smilodon populator Lund, 1842 (Carnivora: Felidae: Machairodontinae) from Venezuela. Ameghiniana, 43(2):499e501.

Rincón, A.D., Prevosti, F.J., and Parra, G.E. 2011. New saber-toothed cat records (Felidae: Machairodontinae) for the Pleistocene of Venezuela, and the Great American Biotic Interchange. Journal of Vertebrate Paleontology, 31(2):468-478. https://doi.org/10.1080/ 02724634.2011 .550366

Roth, S. 1899. Descripción de los restos encontrados en la caverna de Última Esperanza. Revista Museu de La Plata, 9:381-388.

Rusconi, C. 1949. Acerca de una mandíbula de jaguar del Ensenadense. Annales de la Sociedad Cientifica Argentina, 147:189-191.

Sabol, M. 2014. Panthera fossilis (Reichenau, 1906) (Felidae, Carnivora) from Za Hájovnou Cave (Moravia, the Czech Republic): a fossil record from 1987-2007. Acta Musei Nationalis Pragae, Series B, Historia Naturalis, 70(1-2):59-70.

Scanferla, A., Bonini, R., Pomi, L., Fucks, E., and Molinari, A. 2013. New Late Pleistocene megafaunal assemblage with well-supported chronology from the Pampas of southern South America. Quaternary International, 305:97-103. https://doi.org/10.1016/ j.quaint.2012.08.005

Ubilla M., Perea, D., Goso Aguilar, C., and Lorenzo, N. 2004. Late Pleistocene vertebrates from northern Uruguay: tools for biostratigraphic, climatic and environmental reconstruction. Quaternary International, 114:129-142. https://doi.org/10.1016/S1040-6182(03)00048-X 